\title{
Additions of host associations and new records of bat ectoparasites of the families Spinturnicidae, Nycteribiidae and Streblidae from Honduras
}

\author{
Gustavo Graciolli ${ }^{1}$, Hefer D. Ávila-Palma ${ }^{2,3}$, Eduardo J. Ordoñez-Trejo ${ }^{2,4}$, \\ José A. Soler-Orellana ${ }^{2}$, Diego I. Ordoñez-Mazier ${ }^{2}$, Marcio Martínez $^{2,5}$, Richard LaVal ${ }^{6}$, \\ Manfredo A. Turcios-Casco ${ }^{2 *}$
}

1 Instituto de Biociências, Universidade Federal de Mato Grosso do Sul, Campo Grande, Brazil • GG: ggraciolli@yahoo.com.br (® https://orcid. org/0000-0002-1144-3486

2 Asociación para la Sostenibilidad e Investigación Científica en Honduras, Comayagüela, Francisco Morazán, Honduras • HDAP: hefer.avila 77@gmail.com (®ttps://orcid.org/0000-0002-7098-7635•EJOT: edu.ordnz03@gmail.com @ https://orcid.org/0000-0002-8543-5235•JASO: biacuya00@yahoo.com @ https://orcid.org/0000-0002-4175-0751•DIOM: diegoivano@yahoo.com@ (1ttps://orcid.org/0000-0001-6285-662X • MM: sphyrnam@yahoo.es (1) https://orcid.org/0000-0003-3307-6848• MATC: manturcios21@gmail.com (1) https://orcid.org/0000-00023198-3834

3 Panthera Corporation, Tegucigalpa, Francisco Morazán, Honduras

4 Escuela de Biología, Universidad Nacional Autónoma de Honduras, Boulevard Suyapa, Tegucigalpa, Francisco Morazán, Honduras

5 Región Biosfera del Río Plátano, Instituto Nacional de Conservación y Desarrollo Forestal, Áreas Protegidas y Vida Silvestre, Marañones, Olancho, Honduras

6 The Bat Jungle, Monteverde, Costa Rica・RLV: rklaval@gmail.com @ https://orcid.org/0000-0001-7726-9882

* Corresponding author

\begin{abstract}
We captured mormoopids, phyllostomids, and vespertilionids in Honduras to collect bat ectoparasites. Two species of Spinturnicidae (Acari) are the first reports of this family in Honduras. One species of Basilia Miranda Ribeiro, 1903, and four of Streblidae are recorded for the first time in Honduras. With these results, the current species number of each family for Honduras are two species of Spinturnicidae, three of Nycteribiidae, and 48 of Streblidae. We compared the number of species of Streblidae and bats in Honduras to highly sampled countries in Central and South America. Clearly, more effort is still needed in Honduras, although this is the third attempt to study the bat ectoparasites in Honduras.
\end{abstract}

Keywords

Bat flies, Central America, distribution, ectoparasites, mites

Academic editor: Maíra Araújo | Received 28 November 2020 | Accepted 28 February 2021 | Published 9 March 2021

Citation: Graciolli G, Ávila-Palma HD, Ordoñez-Trejo EJ, Soler-Orellana HA, Ordoñez-Mazier DI, Martínez M, LaVal R, Turcios-Casco MA (2021) Additions of host associations and new records of bat ectoparasites of the families Spinturnicidae, Nycteribiidae and Streblidae from Honduras. Check List 17 (2): 459-469. https://doi.org/10.15560/17.2.459 


\section{Introduction}

Bats are the order of mammals with the second largest number of species ( $>1,400$ species) (Simmons and Cirranelo 2020). As the only mammals capable of flight, they have a worldwide distribution, except Antarctica. Bats harbor a diverse community of ectoparasitic arthropods (Marshall 1981; Whitaker et al. 2009), with some groups occurring exclusively on them. Among these, the most frequent groups found on bats are wing mites of the family Spinturnicidae (Acari) and bat flies of the families Streblidae and Nycteribiidae (Diptera).

Spinturnicid mites are viviparous, hematophagous, and pass their entire life cycle on bats (Dowling 2006). There are five genera and 40 species of spinturnicids recorded in the Americas, collected on bats of the families Vespertilionidae, Phyllostomidae, Mormoopidae, and Natalidae (Dusbábek 1968; Almeida et al. 2016). Previous to this work, there were no records of spinturnicid mites from Honduras. As for other countries of Central America, the accounts are as follows: 15 species in Panama, 14 species in Mexico, one in Belize, and five in Costa Rica (Herrin and Tipton 1975; Almeida et al. 2016).

In the Americas, there are 166 species of 26 genera of streblid bat flies divided into three subfamilies (Dick and Miller 2010; Graciolli and Azevedo 2011; Graciolli and Dick 2012; Reeves et al. 2013; Alcantara et al. 2019). Streblid bat flies occur on Phyllostomidae, Mormoopidae, Noctilionidae, Natalidae, Vespertilonidae, and Molossidae (Dick and Miller 2010). For Honduras, Dick (2013) summarized a total of 43 species and 17 genera of Streblidae, collected from nine of the 18 Honduran departments. After his work, there has been only one more study reporting bat flies from Honduras (Miller 2014), collected in Utila, Islas de la Bahía in northern Honduras, with a new record for the country, Trichobius angulatus Wenzel, 1976. This brings the total number of species to 44 .

For Nycteribiidae, there are two genera from the Americas: Basilia Miranda-Ribeiro, 1903 with 55 species, divided into five morphological groups that are mainly found on vespertilionid bats (Graciolli 2010). However, two species are found on bats of the genus Gardnerycteris Hurtado \& Pacheco, 2014. Hershkovitzia Guimarães \& D'Andretta, 1956 has four species that parasitize bats of the family Thyropteridae (Graciolli et al. 2007; Graciolli and Dick 2009; Graciolli 2010). There are also few species recorded for the countries adjoining Honduras. Thus, two species of Basilia for Belize, three species for Guatemala, and five species each for El Salvador and Nicaragua. Only two species of Basilia had been reported for Honduras, B. rondanii Guimarães \& D'Andretta, 1956 and B. dubiaquercus Graciolli \& Dick, 2009 (Graciolli et al. 2007; Graciolli and Dick 2009).

Here we report for the first time for Honduras the family Spinturnicidae based on two species, as well as a new record of Nycteribiidae and four new records of
Streblidae for the country. Also, we give ecological comments on the ectoparasites and their hosts.

\section{Methods}

We captured bats with two mist nets $(12 \times 2.5 \mathrm{~m}$ with denier mesh of $35 \mathrm{~mm}$ ) that were set at ground level and opened from 17:20 to 01:30 h. Their position at each site was selected based on the surrounding vegetation and topography, and also considering water bodies, if available, and fruiting and flowering plants (Kunz and Kurta 1988). All the bats were manipulated according to the guidelines for the use of mammals in wildlife research (Sikes et al. 2019).

We used forceps to remove all ectoparasites in the field and placed them in vials containing $70 \%$ ethanol. The ectoparasites were identified in the laboratory using keys for American streblid bat flies of Wenzel et al. (1966), Wenzel (1976), and Guerrero (2019); nycteribiid bat flies were identified based on Guimarães (1977) and Graciolli (2004); and spinturnicid mites were identified according to Herrin and Tipton (1975). All the specimens were deposited at the Zoological Collection at Federal University of Mato Grosso do Sul (ZUFMS). Collecting license (Resolución-DE-MP-064-2017) and exportation permit (Constancia ICF-DVS-27-2017) was provided by the Wildlife Department of the Instituto Nacional de Conservación y Desarrollo Forestal, Áreas Protegidas y Vida Silvestre (ICF).

\section{Results}

Two species of Periglischrus (Spinturnicidae), one of Basilia (Nycteribiidae), and one each of the streblid genera Aspidoptera Coquillett, 1899, Neotrichobius Wenzel \& Aitken, 1966, Strebla Wiedemann, 1984, and Trichobius Gervais, 1844 are recorded for the first time in Honduras. The new records in separate localities increase the number of species of Basilia to three and of Streblidae to 48 species (Fig. 1). In overall we describe seven new records of bat ectoparasites and 12 hosts for Honduras.

Spinturnicidae

\section{Periglischrus iheringi Oudemans, 1902}

Material examined. HONDURAS • Francisco Morazán, Ciudad Universitaria; $14^{\circ} 05^{\prime} 14^{\prime \prime} \mathrm{N}, 087^{\circ} 09^{\prime} 60^{\prime \prime} \mathrm{W}, 1100 \mathrm{~m}$ a.s.1.; 19 Nov. 2015; Manfredo A. Turcios-Casco, Hefer D. Ávila-Palma, Eduardo J. Ordoñez-Trejo, José A. SolerOrellana, Diego I. Ordoñez-Mazier leg.; the host was Artibeus jamaicensis Leach, 1821; 1 \&, ZUFMS-ART2361.

Identification. The females of Periglischrus iheringi (Fig. 3A) can be identified by having the sternal setae longer; the first pair extending to or beyond the level of the second pair of setae; the intercoxa IV area has eight pairs of setae; and because the proximal anterior and posterior dorsal setae are longer and subequal in length (Herrin and Tipton 1975). 


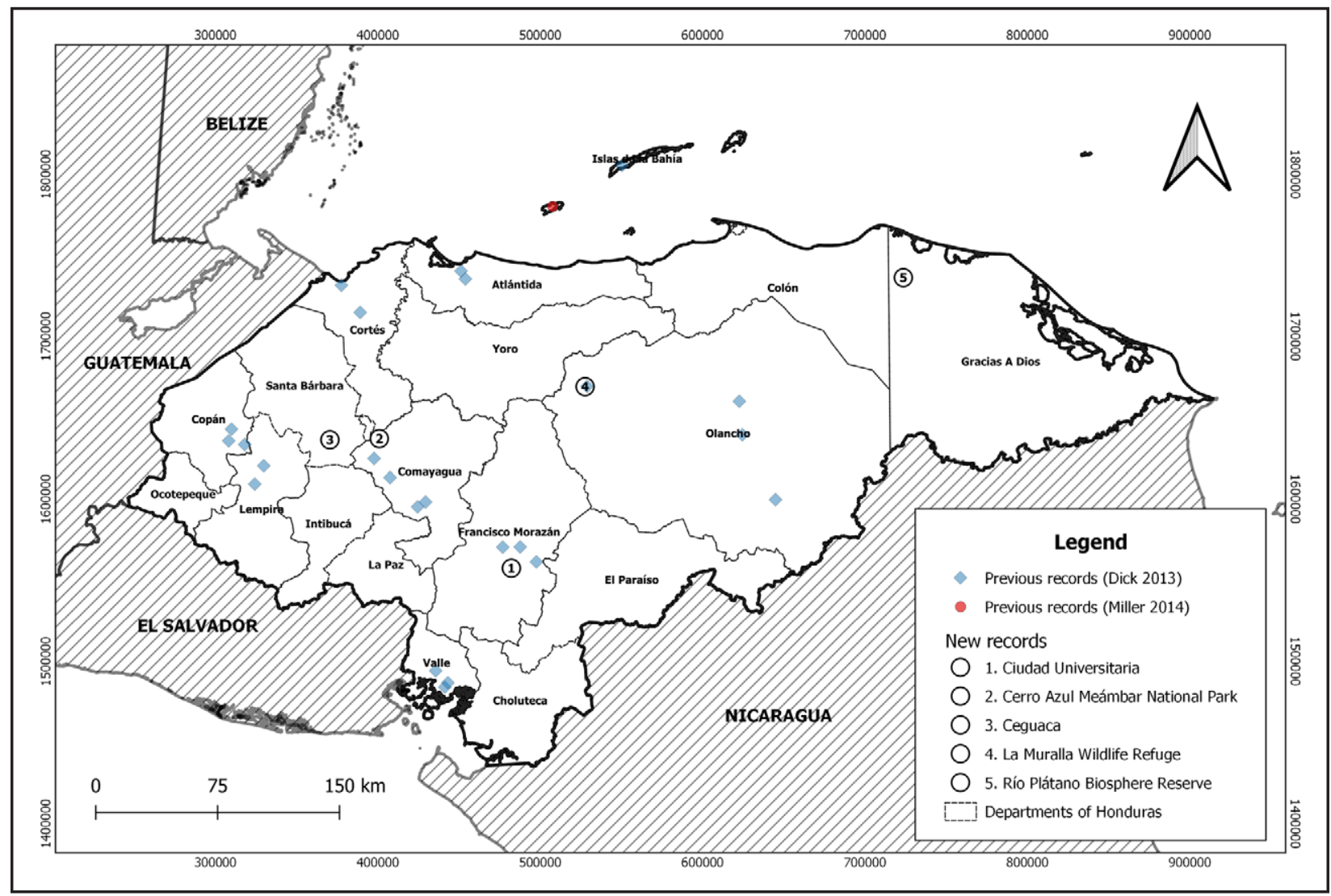

Figure 1. Study sites and sites mentioned by Dick (2013) and Miller (2014).

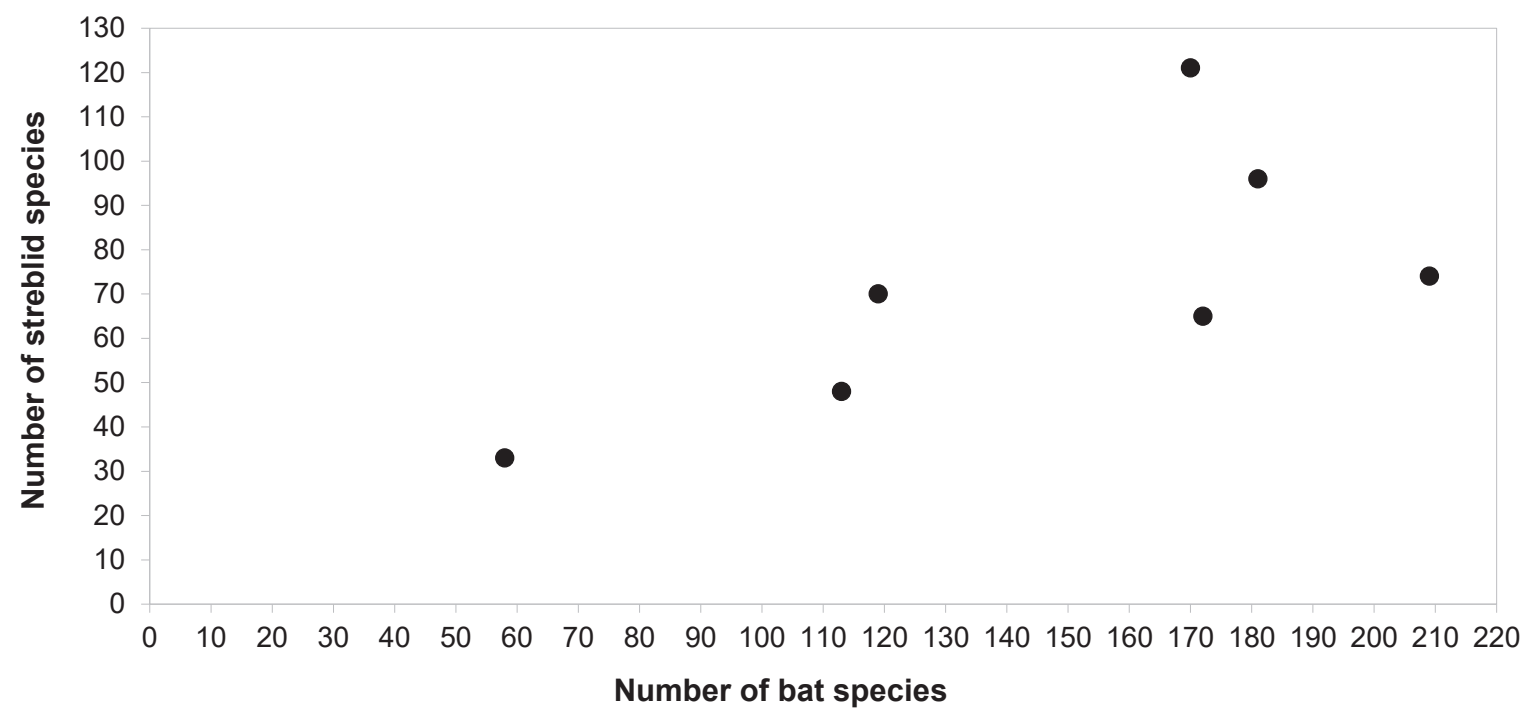

Figure 2. Number of species of Streblidae and Chiroptera in Central and South America according to Table 1.

Table 1. Number of species of Chiroptera and of Streblidae in Brazil, Colombia, Honduras, Panama, Paraguay, Peru, and Venezuela.

\begin{tabular}{lclcl}
\hline Country & Number of bat species & Source & Number of streblid species & Source \\
\hline Colombia & 209 & Ramírez-Chaves et al. 2020 & 74 & Marinkelle and Grose 1981; Dick et al. 2016 \\
Brazil & 181 & Garbino et al. 2020 & 96 & Graciolli 2020 \\
Peru & 172 & Díaz et al. 2016 & 65 & Guerrero 1996b; Autino et al. 2011 \\
Venezuela & 170 & Díaz et al. 2016 & 121 & Wenzel 1976; Guerrero 2019 \\
Honduras & 113 & Turcios-Casco et al. 2020 & 48 & Dick 2013; Miller 2014, this study \\
Panama & 119 & Estrada-Villegas et al. 2018 & 70 & Wenzel et al. 1966 \\
Paraguay & 58 & De la Sancha et al. 2017 & 33 & Dick and Gettinger 2005 \\
\hline
\end{tabular}



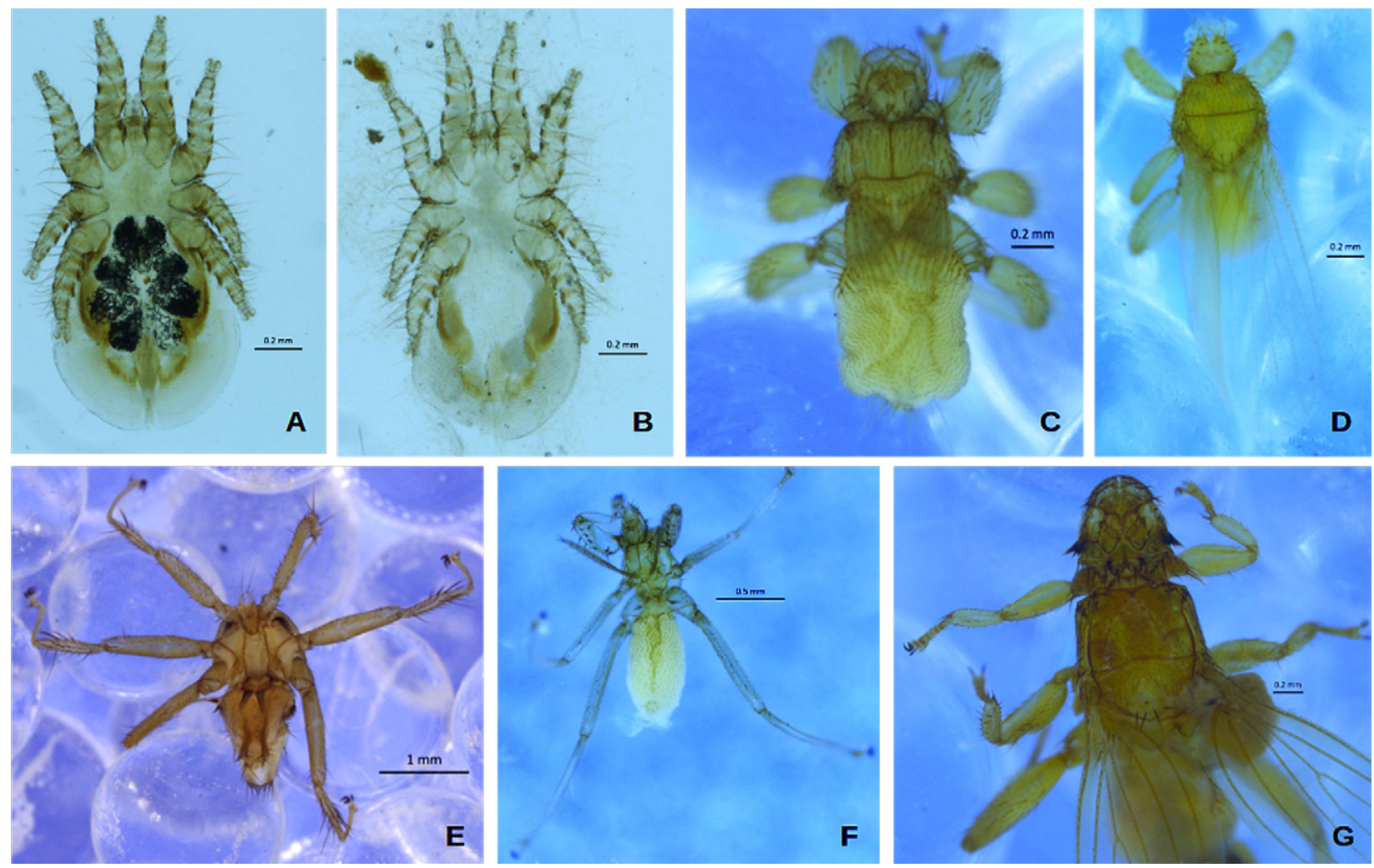

Figure 3. Species of ectoparasites recorded for the first time in Honduras. A. Periglischrus iheringi Oudemans (Spinturnicidae). B. Periglischrus ojastii Machado-Allison (Spinturnicidae). C. Aspidoptera delatorrei Wenzel (Streblidae). D. Trichobius yunkeri Wenzel (Streblidae). E. Basilia ortizi Machado-Allison (Nycteribiidae). F. Neotrichobius bisetosus Wenzel (Streblidae). G. Strebla matsoni Wenzel (Streblide).

Remarks. Previously, Periglischrus iheringi was recorded in Bolivia, Brazil, Colombia, Costa Rica, Cuba, Mexico, Panama, Paraguay, Peru, Puerto Rico, Saint Kitts, Suriname, Trinidad and Tobago, and Venezuela (Dusbábek and Lukoschus 1971; Beck et al. 2016; Gettinger 2018) (Fig. 4). Periglischrus iheringi is found on various species and genera of stenodermatine bats (Herrín and Tipton 1975; Gettinger 2018) but occur mainly on bats of the genera Artibeus Leach, 1821, Platyrrhinus Saussure, 1860, and Uroderma Peters, 1865 (Herrin and Tipton 1975).

\section{Periglischrus ojastii Machado-Allison, 1964}

Material examined. HONDURAS • Francisco Morazán, Ciudad Universitaria; $14^{\circ} 05^{\prime} 14^{\prime \prime} \mathrm{N}, 087^{\circ} 09^{\prime} 60^{\prime \prime} \mathrm{W}, 1100$ m a.s.1.; 19 Dec. 2015; Manfredo A. Turcios-Casco, Hefer D. Ávila-Palma, Eduardo J. Ordoñez-Trejo, José A. Soler-Orellana, Diego I. Ordoñez-Mazier leg.; the hosts were Sturnira parvidens Goldman, 1917; 1 \%, ZUFMSART2362; 1 đ̃, ZUFMS-ART2363.

Material examined. HONDURAS • Comayagua, Cerro Azul Meámbar National Park, Cerro Azul Community; $14^{\circ} 48^{\prime} 19^{\prime \prime} \mathrm{N}, 087^{\circ} 55^{\prime} 21^{\prime \prime} \mathrm{W} ; 965 \mathrm{~m}$ a.s.1.; 10 May 2016; Manfredo A. Turcios-Casco, Hefer D. Ávila-Palma, José A. Soler-Orellana, Diego I. Ordoñez-Mazier leg.; the host was $S$. parvidens; 1 , ZUFMS-ART2364.

Identification. Periglischrus ojastii (Fig. 3B) can be identified by having the first pair of dorsal podosomal setae of females subequal in length to the other podosomal setae located on the anterolateral integument of the dorsal plate. In both sexes the distance between the first and second pairs of podosomal setae is distinctly less than the distance between the second and third pairs. The posteroventral setae of femur IV, patella IV, and tibia IV are straight and bladelike in females (Herrin and Tipton 1975).

Remarks. Previously P. ojastii was recorded in Brazil, Bolivia, Colombia, Costa Rica, Dominica, Mexico, Panama, Peru, and Venezuela (Dick et al. 2007; Gettinger 2018) (Fig. 5). This species is, in general, found on bats of the genus Sturnira Gray (Gettinger 2018).

Nycteribiidae

\section{Basilia ortizi Machado-Allison, 1964}

Material examined. HONDURAS - Gracias a Dios, Río Plátano Biosphere Reserve World Heritage Site, Las Marías, Las Marías Pesh Tribal Council; 1540'32"N, 08450'35"W, 33 m a.s.1.; 02 Sept. 2017; Hefer D. ÁvilaPalma, Diego I. Ordoñez-Mazier, Marcio Martínez leg.; the hosts were Eptesicus furinalis (d'Orbigny, 1847); 1 , ZUFMS-ART2365; 1 \%, ZUFMS-ART2366.

Identification. Basilia ortizi (Fig. 3E) belongs to the ferruginea group. The females have two abdominal tergites, and the second one has a posterior margin with two lobes. Basilia ortizi can be recognized by having a digitiform process in the mesonotum; an abdominal connexivum with shorter setae; and the lobules of tergite II are longer than wider, with one to three long spiniform setae 


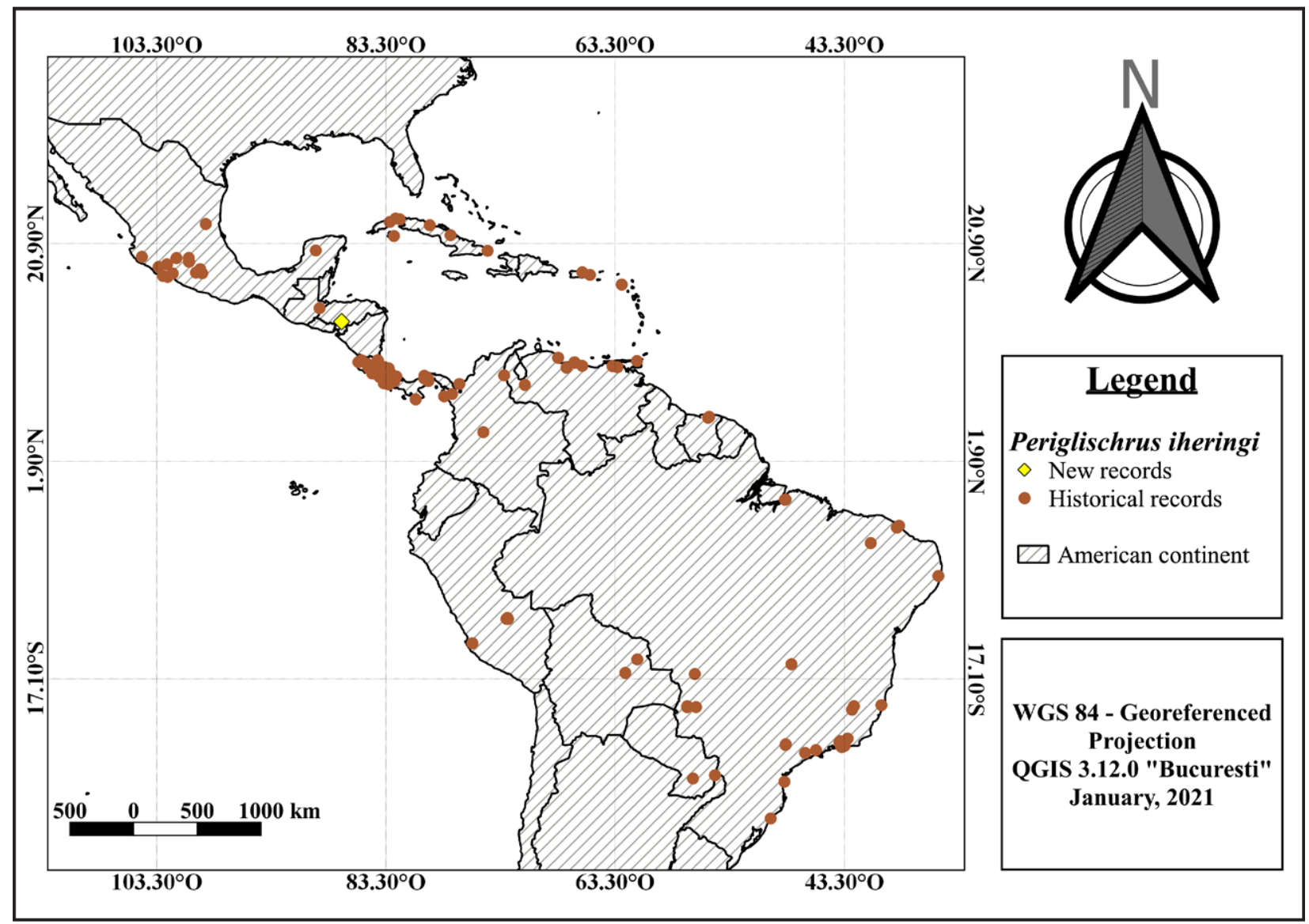

Figure 4. Historical and new records of Periglischrus iheringi in the Americas.

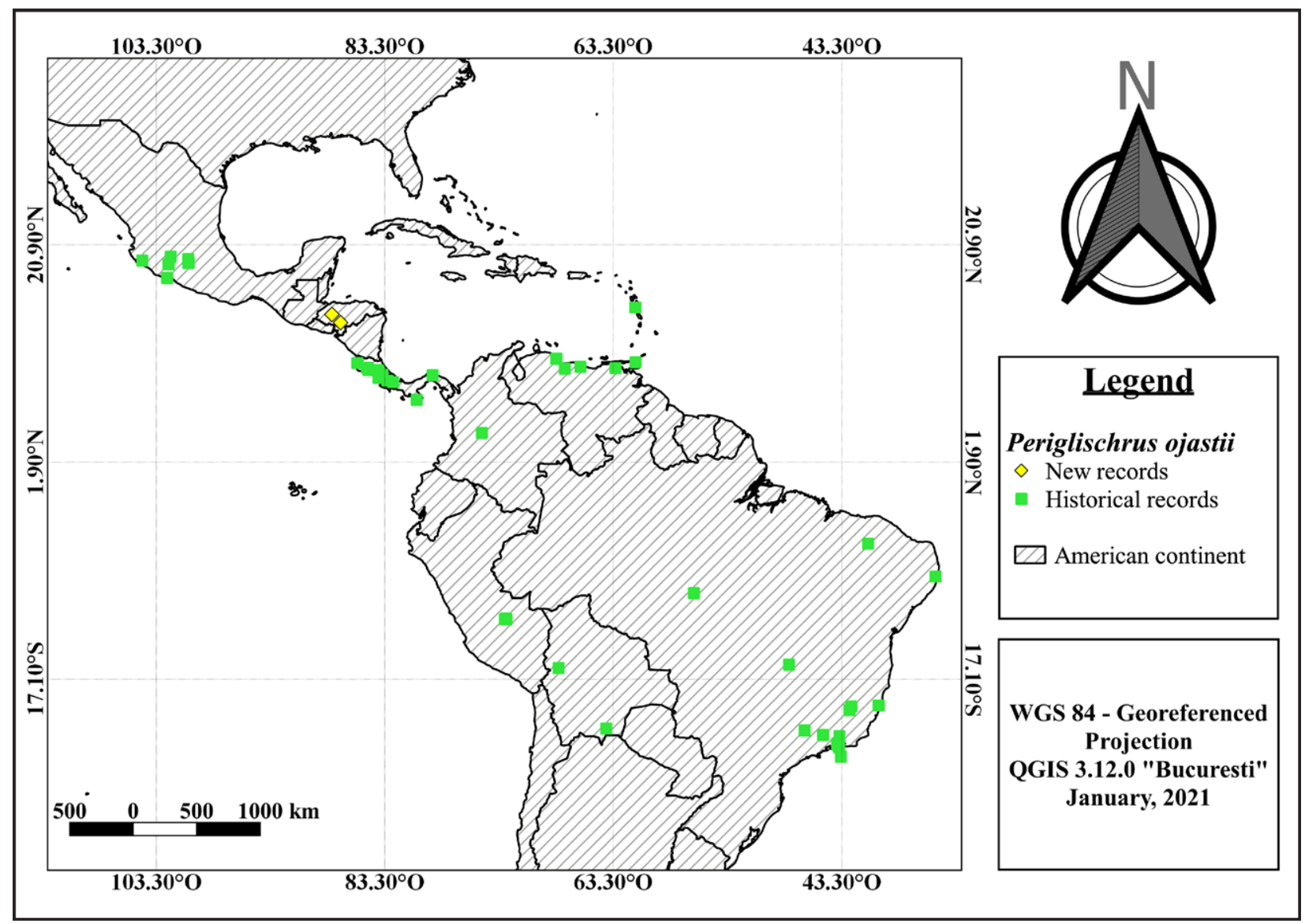

Figure 5. Historical and new records of Periglischrus ojastii in the Americas. 
and one to seven short spiniform setae (Guimarães 1977; Graciolli 2004).

Remarks. Basilia ortizi was previously recorded in Belize, Costa Rica, French Guiana, Venezuela, and Brazil (Graciolli et al. 2007; Graciolli et al. 2019) (Fig. 6) and found on Enchisthenes hartii (Thomas, 1892), Eptesicus brasiliensis (Desmarest, 1819), E. diminutus Osgood, 1915, E. furinalis, Myotis nigricans (Schinz, 1821), and M. riparius Handley, 1960 (Graciolli et al. 2007; Urbieta et al. 2018).

\section{Streblidae}

\section{Aspidoptera delatorrei Wenzel, 1966}

Material examined. HONDURAS • Comayagua, Cerro Azul Meámbar National Park, Cerro Azul Community; $14^{\circ} 48^{\prime} 19^{\prime \prime} \mathrm{N}, 087^{\circ} 55^{\prime} 21^{\prime \prime} \mathrm{W} ; 965$ m a.s.1.; 10 May 2016; Manfredo A. Turcios-Casco, Hefer D. Ávila-Palma, José A. Soler-Orellana, Diego I. Ordoñez-Mazier leg.; the hosts were Sturnira parvidens; respectively, 1 q, ZUFMS-ART2367; 1 §, ZUFMS-ART2368.

Material examined. HONDURAS • Olancho, La Muralla Wildlife Refuge; $15^{\circ} 05^{\prime} 48^{\prime \prime} \mathrm{N}, \quad 086^{\circ} 44^{\prime} 41^{\prime \prime} \mathrm{W}$; 1486 m a.s.l.; 21 Apr. 2017; Hefer D. Ávila-Palma leg.; host was Sturnira hondurensis Goodwin, 1940; $1 \hat{\jmath}$, ZUFMS-ART2369.

Identification. Aspidoptera delatorrei (Fig. 3C) can be differentiated from A. phyllostomatis Perty, 1833 because the latter has a smaller mesespisternum (seen from dorsal view), and from A. falcata Wenzel, 1976 because the former has two epiproct setae and less curved gonopods (Guerrero 1994b).

Remarks. Previously, A. delatorrei was recorded in Belize, Colombia, Guatemala, Mexico, Nicaragua, Panama, Peru, and Venezuela (Guerrero 1994a; ter Hofstede et al. 2004) (Fig. 7). It is mainly found on bats of the genus Sturnira (Guerrero 2019).

\section{Neotrichobius bisetosus Wenzel, 1976}

Material examined. HONDURAS - Gracias a Dios, Río Plátano Biosphere Reserve World Heritage Site, Pico Dama, Las Marías Pesh Tribal Council; 1541'39"N, 08454'56"W; 383 m a.s.1.; 08 Sept. 2017; Hefer D. ÁvilaPalma, Diego I. Ordoñez-Mazier, Marcio Martínez leg.; host was Vampyressa thyone Thomas, 1909; 1 ㅇ, ZUFMS-ART2370.

Identification. Individuals of $N$. bisetosus (Fig. 3F) can be differentiated from $N$. delicatus and $N$. ectophyllae because in $N$. bisetosus the second vein does not reach the apex and only extends, like a spur, a little beyond from the r-m; in Neotrichobius stenopterus Wenzel \& Aitken, 1966 there are four scutelar setae.

Remarks. Neotrichobius bisetosus is the second species of its genus recorded in Honduras; the first is $N$. stenopterus. N. bisetosus was previously known for Bolivia, Brazil, Colombia, French Guiana, Panama, Peru,

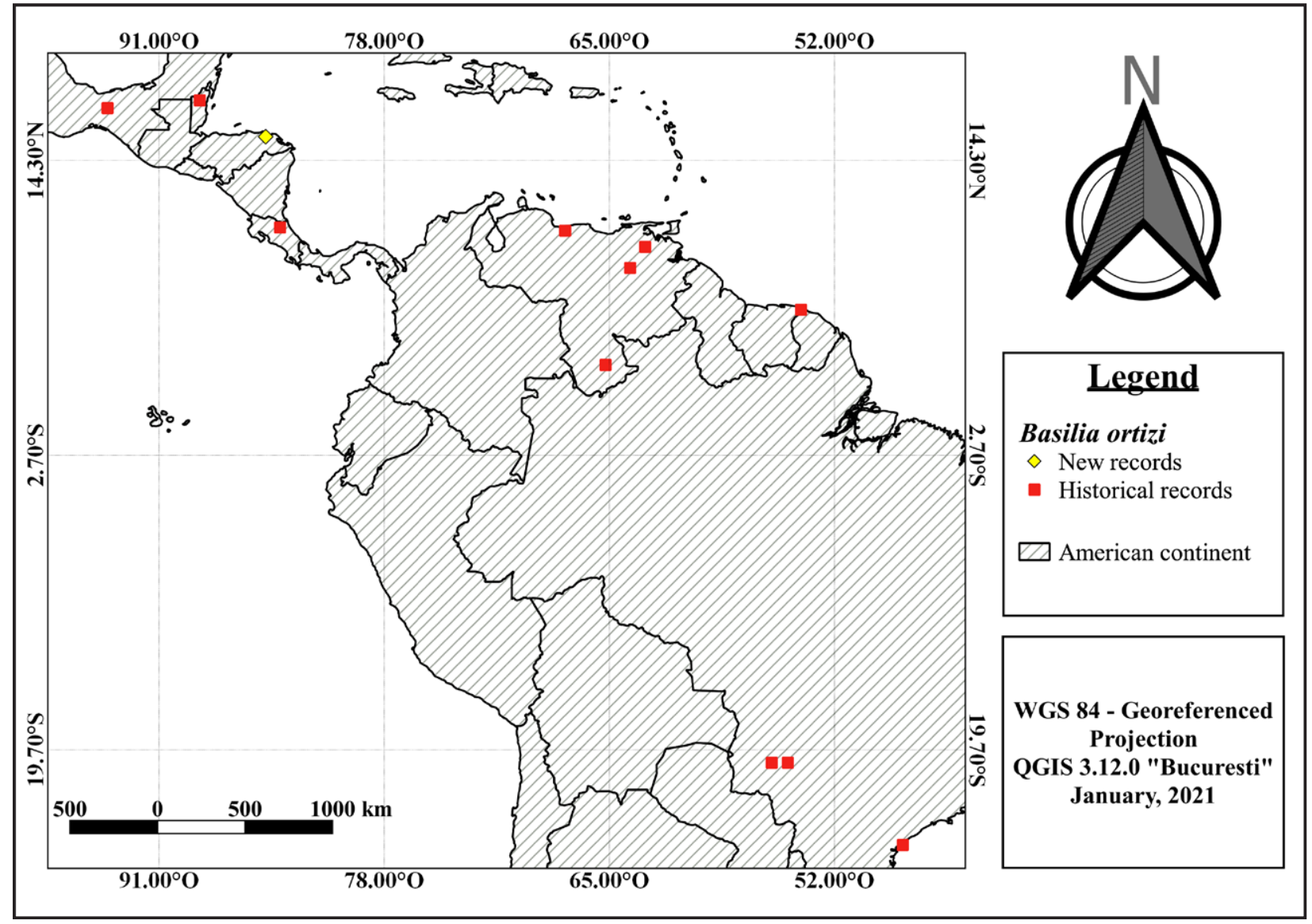

Figure 6. Historical and new records of Basilia ortizi in the Americas. 


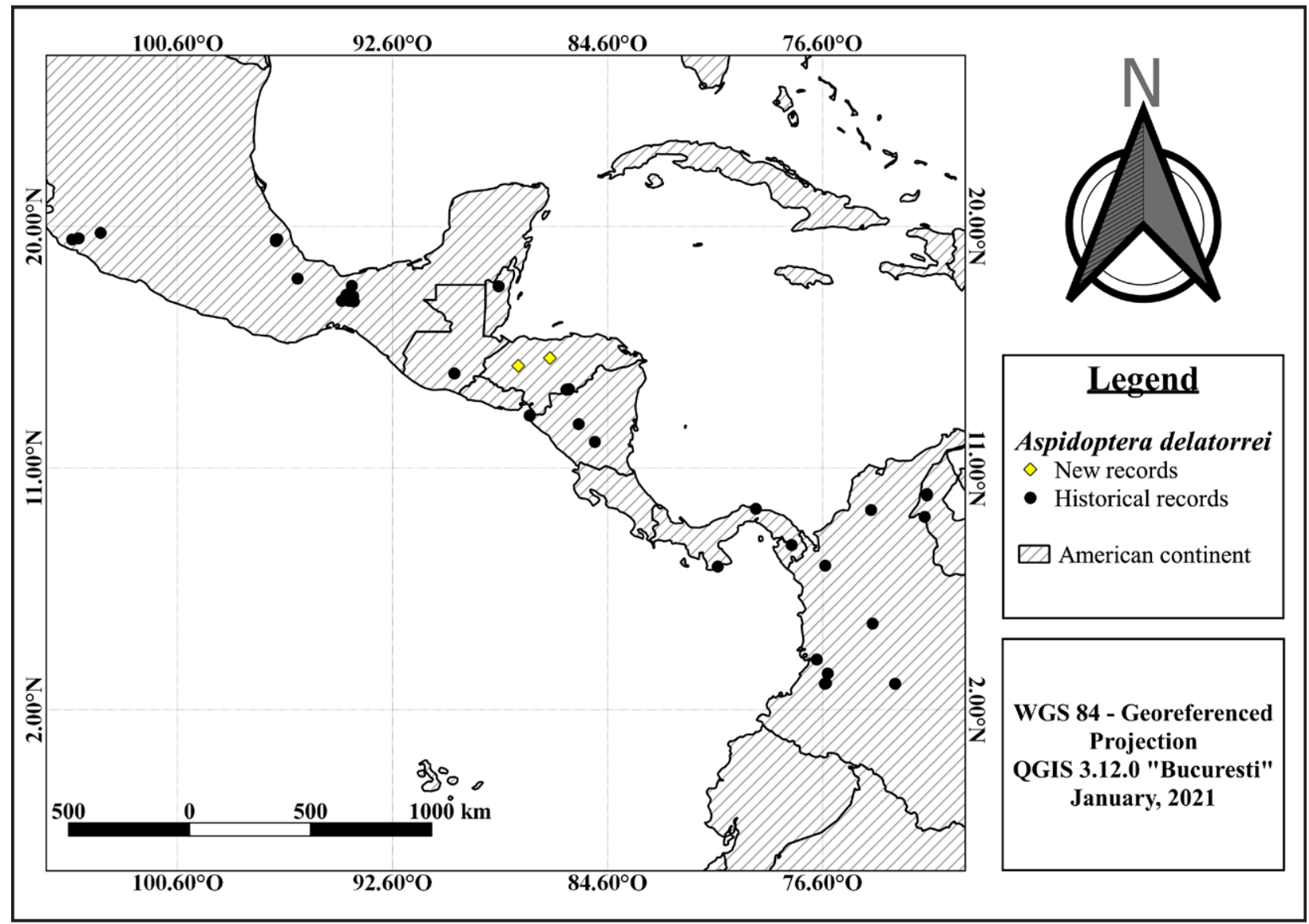

Figure 7. Historical and new records of Aspidoptera delatorrei in the Americas.

Suriname, and Venezuela (Dick et al. 2016; Graciolli et al. 2019; Guerrero 2019; Hrycyna et al. 2019) (Fig. 8). The main host of $N$. bisetosus is Artibeus obscurus (Schinz, 1821) (Guerrero 2019), but it had been found on other species of Artibeus, Phyllostomus hastatus (Pallas, 1767), and a natalid bat, Natalus stramineus Gray, 1838 (Guerrero 2019). This is the first record on $V$. thyone, and we consider this association with this bat species to be accidental or transitory

\section{Strebla matsoni Wenzel, 1976}

Material examined. HONDURAS • Santa Bárbara, Área de Importancia para la Conservación de Murciélagos Ceguaca, Mujer de los Juncos; 1447'50"N, 088 $12^{\prime} 19^{\prime \prime} \mathrm{W}$; 515 m a.s.1.; 21 Dec. 2015; Manfredo A. Turcios-Casco, Hefer D. Ávila-Palma, Eduardo J. Ordoñez-Trejo, José A. Soler-Orellana, Diego I. Ordoñez-Mazier leg.; host was Artibeus jamaicensis; 1 q, ZUFMS-ART2371.

Identification. Strebla matsoni (Fig. 3G) can be identified by its frontoclypeus, which has a pair of apical plates that are separated from the anterior border; although large, it is difficult to see (Guerrero 1996a). Eyes with eight facets. Post-vertex with short, thin setae, especially the internal occipital plates, which are very short; anterior end pointed, with an angle of approximately $120^{\circ}$ (Guerrero 1996a). Mesonotum without visible spaces; row before the pigmented suture, and setae equal to or slightly longer than the rest giving a very uniform appearance; with three rows of setae between the transverse suture and the pigmented suture (Guerrero 1996a).

Remarks. This is often considered a rare species of Strebla (Guerrero 1996a). The only known collected specimens of this species were the type material which consists of two males and one female from Venezuela (Fig. 9). The previous records were collected on Macrophyllum macrophyllum (Schinz, 1821), Carollia perspicillata (Linnaeus, 1758) (Phyllostomidae), and Rhynchonycteris naso (Wied-Neuwied, 1820) (Emballonuridae) (Guerrero 1996a, 1996b). Thus, A. jamaicensis is recorded for the first time as a host of $S$. matsoni.

\section{Trichobius yunkeri Wenzel, 1966}

Material examined. HONDURAS • Comayagua, Cerro Azul Meámbar National Park, Cerro Azul Community; $14^{\circ} 48^{\prime} 19^{\prime \prime} \mathrm{N}, 087^{\circ} 55^{\prime} 21^{\prime \prime} \mathrm{W}$; $965 \mathrm{~m}$ a.s.l.; 09 May. 2016; Manfredo A. Turcios-Casco, Hefer D. Ávila-Palma, José A. Soler-Orellana, Diego I. Ordoñez-Mazier leg.; host was Pteronotus mesoamericanus Smith, 1972; 1 गे, ZUFMS-ART2373.

Identification. Trichobius yunkeri (Fig. 3D) is similar to Trichobius caecus Edwards, 1918. The former has two long discal setae in the tergite 7; the sternite VII may have more than five macrosetae in the posterior margin; T. caecus has a tiny discal seta in the tergite VII and has three or four setae in the posterior margin (Guerrero 1995).

Remarks. Trichobius yunkeri was known from Belize, 


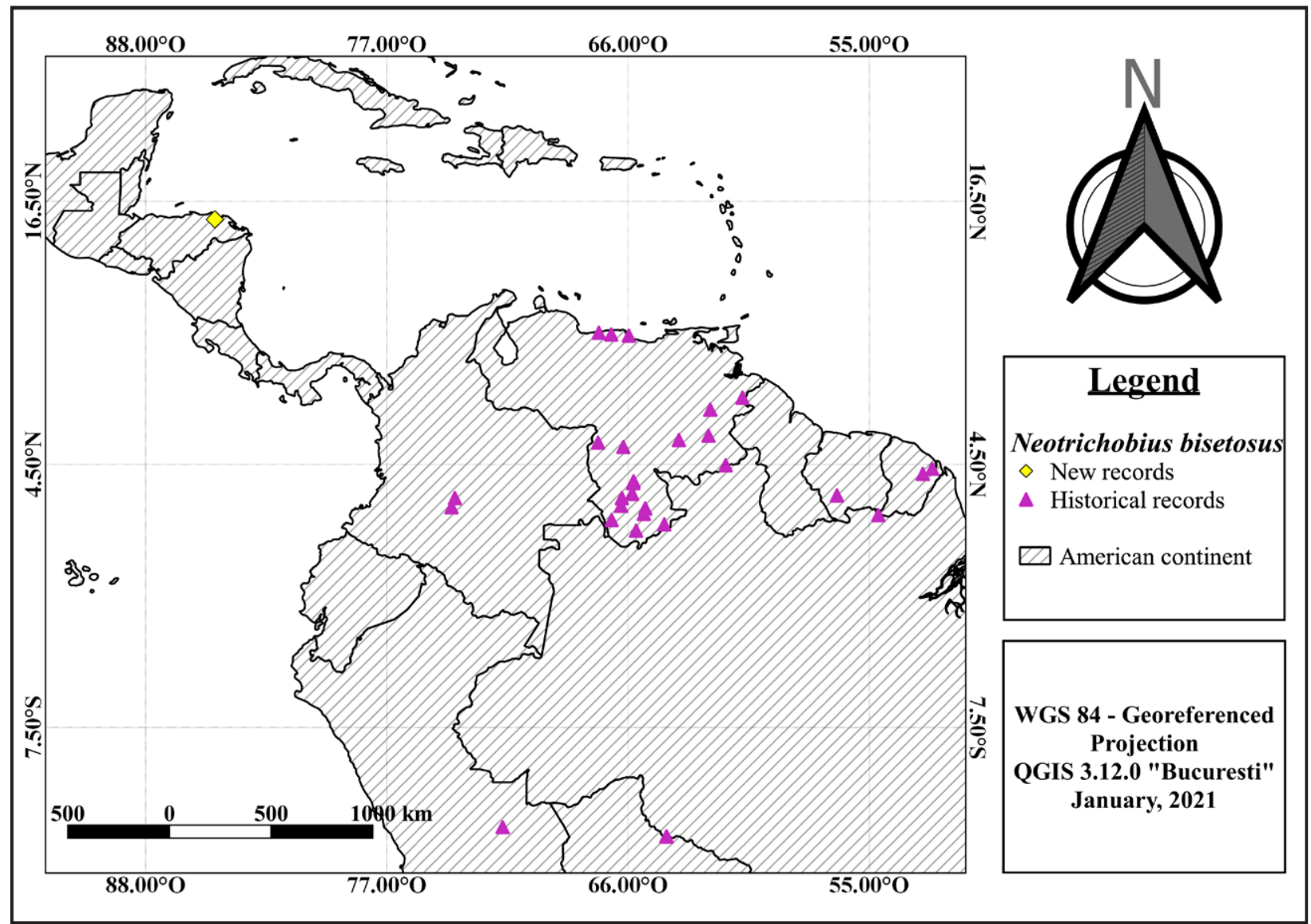

Figure 8. Historical and new records of Neotrichobius bisetosus in the Americas.

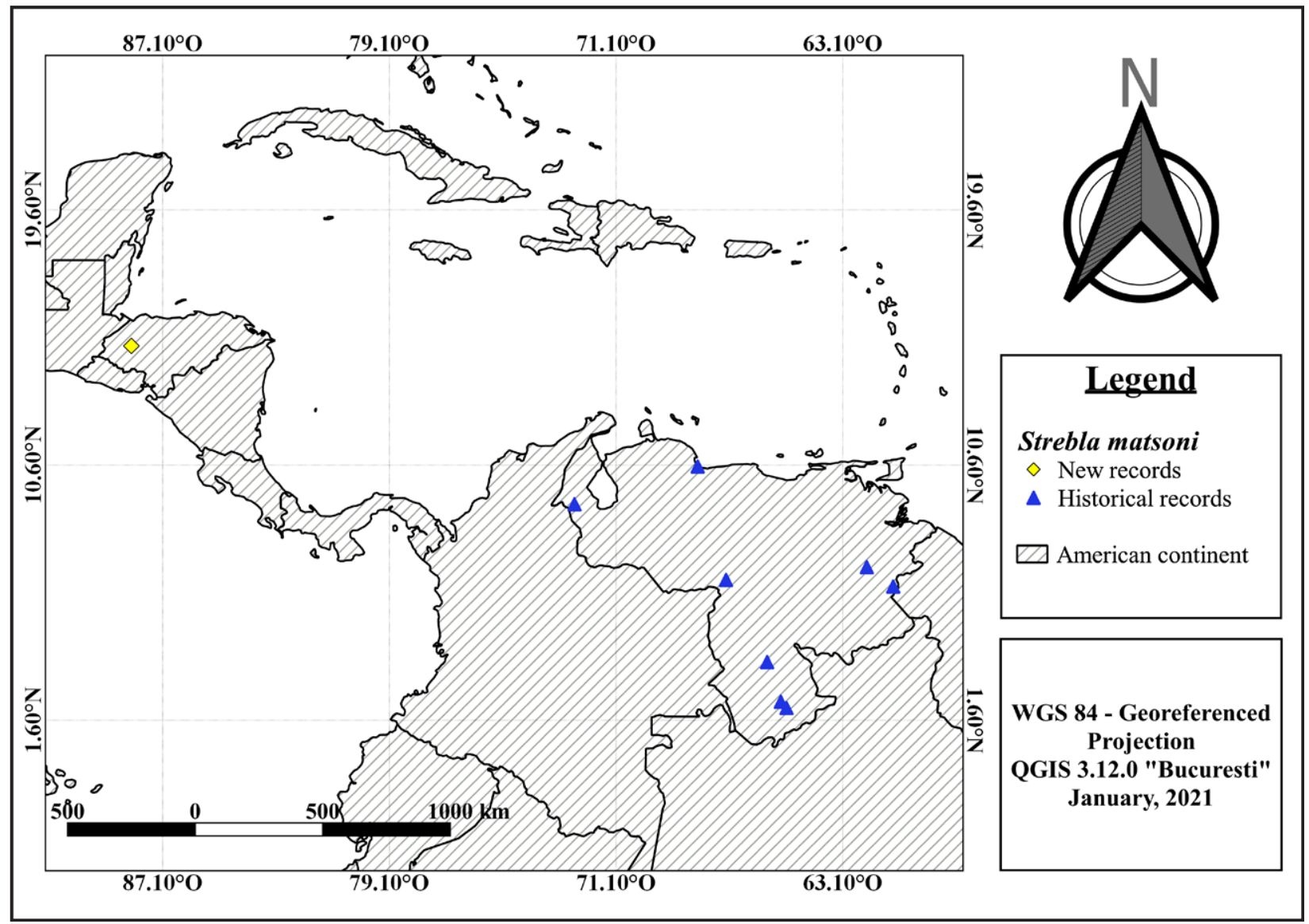

Figure 9. Historical and new records of Strebla matsoni in the Americas. 


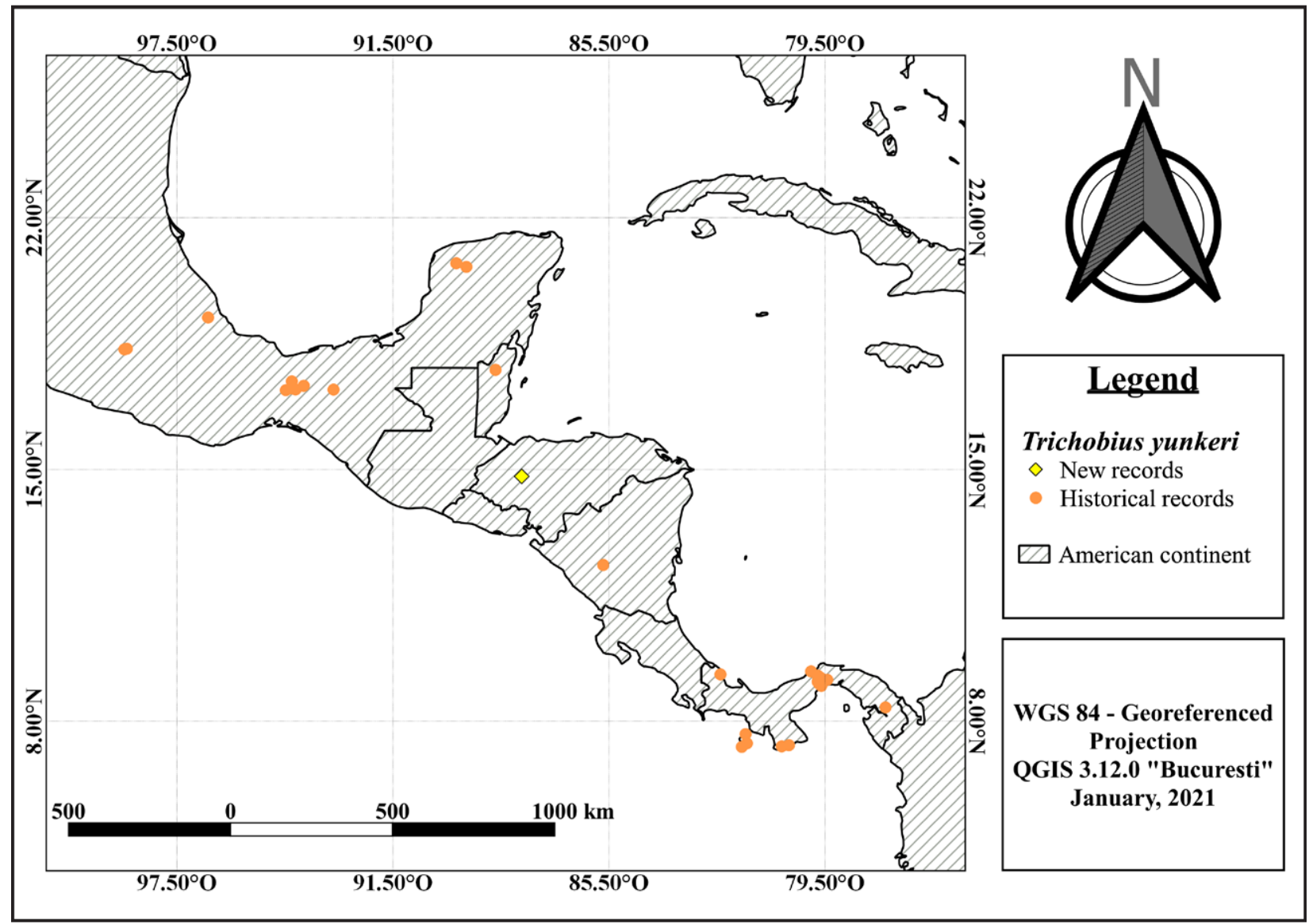

Figure 10. Historical and new records of Trichobius yunkeri in the Americas.

Guatemala, Mexico, Nicaragua, and Peru (Guerrero 1994b; ter Hofstede et al. 2004) (Fig. 10), but Guerrero (1994a) considered the record from Peru as doubtful. Various authors stated that subspecies of Pteronotus parnelli (Gray, 1843) were the hosts of T. yunkeri (Guerrero 1994a; ter Hofstede et al. 2004; Ramírez-Martínez et al. 2017). However, Pavan and Marroig (2016) elevated some subspecies of $P$. parnelli to full species. Therefore, it seems likely that the record for Belize (ter Hofstede et al. 2004) is from P. mexicanus (Miller, 1902), and for Panama, the host is $P$. rubiginosus (J.A. Wagner, 1843).

\section{Discussion}

Currently, 113 bat species have been recorded in Honduras (Turcios-Casco et al. 2020), but of these, only 36 are known to have spinturnicid mites and/or bat flies. As our data are the first records of spinturnicid mites in Honduras, it is obvious that much more effort is needed to understand this group in Central America. For example, studies in South America and Mexico led to the description of new species (Almeida et al. 2016; Morales-Malacara et al. 2020).

Honduran nycteribiid bat flies were recorded only on three species of vespertilionid bats (i.e., Myotis nigricans, Myotis pilosatibialis LaVal, 1973, and Bauerus dubiaquercus (Van Gelder, 1959)). However, the difficult identification of vespertilionid and molossid bats has hindered associations of Nycteribiidae with their hosts. The genus Basilia potentially can be found in the other 14 species of vespertilionid bats, and species of Hershkovitzia should be found on Thyroptera tricolor Spix, 1823. Our record of B. ortizi on E. furinalis is the first for the country and is the fourth vespertilionid species known to be parasitized by $B$. ortizi.

Although streblid flies represent the majority of the bat ectoparasites that have been studied in Honduras, the intensification of new collections may considerably increase the number of species. In Honduras, streblid flies have been found only on 27 of the 59 phyllostomid species (Dick 2013; this paper). For Mormoopidae, only $P$. mesoamericanus has been reported to be parasitized by a streblid fly, and there are three more species of Pteronotus and Mormoops megalophylla (Peters, 1864) in Honduras (Turcios-Casco et al. 2020). As is the case with spinturnicid mites, there is a chance to discover undescribed species, as well as to encounter new records. Recent taxonomic reviews have found unexpected diversity of bat flies. For example, Alcantara et al. (2019) reviewed the genus Noctiliostrebla Wenzel, 1966, which had four previously described species, and described seven new species. Noctiliostrebla is known to parasitize the two species of Noctilio Linnaeus, 1766.

Important surveys of streblids and their hosts were carried out in Brazil (Graciolli 2020), Colombia (Marinkelle and Grose 1981; Dick et al. 2016), Panama (Wenzel 
et al. 1966), Paraguay (Dick and Gettinger 2005), Peru (Guerrero 1996b; Autino et al. 2011), and Venezuela (Wenzel 1976; Guerrero 2019) (Table 1). If we consider the number of bat fly species as a variable dependent on the number of bat species, the number of bat species is a good predictor of the number of streblid species (see Dick and Gettinger 2005). For example, Figure 2 shows that Venezuela is the best-surveyed country with the greatest number of Streblidae, and that the number of bat fly species in Panama to Peru is as many as 60 per country (Fig. 2; Table 1). So far, we have increased the number of streblid flies in Honduras to 48.

To our knowledge, this is the third attempt to study bat ectoparasites in Honduras. The previous study was by Miller (2014). Seven years later, we present seven new records for Honduras: Periglischrus iheringi, P. ojastii, Basilia ortizi, Aspidoptera delatorrei, Neotrichobius bisetosus, Strebla matsoni, and Trichobius yunkeri, plus the first record of Spinturnicidae for Honduras, the northernmost record of $N$. bisetosus, and a new locality (it was previously known only from Venezuela) and a new host ( $A$. jamaicensis) for $S$. matsoni. However, the ecology, behavior, and morphology of bat ectoparasites are poorly studied and understood. Among the studied sites, the Río Plátano Biosphere Reserve is the most important in Honduras for research and conservation, not only due to its high biodiversity but because it is a poorly studied. As suggested above, additional surveys in the Honduras should increase the number of species of Spinturnicidae, Nycteribiidae, and Streblidae, and even new species may be found.

\section{Authors' Contributions}

GG identified all the specimens; MATC, HDAP, EJOT, JASO, MM, and DIOM conceived and coordinated the surveys of the records; DIOM made the distribution maps. All the authors were involved in the writing of the manuscript, and read, edited, and approved the manuscript.

\section{Acknowledgements}

We are thankful to Don Beto $†$ and his family in Ceguaca, Santa Bárbara. Most of the effort done in Ciudad Universitaria was with the support of Nereyda Estrada and the Vertebrate Laboratory of the School of Biology of the Universidad Nacional Autónoma de Honduras. Also, we want to thank all the students of CU-UNAH that participated in the surveys. Special thanks go to the community of Cerro Ázul in Comayagua for their support in the surveys. Most of the work at the Zoological Collection at Federal University of Mato Grosso do Sul regarding this manuscript was done with support from the financial agency CNPq \# 306216/2018-3. We thank the Las Marías Pesh Tribal Council for permitting our research on their territory. Finally, we thank Marcel Santos de Araújo, two anonymous reviewers, Robert Forsyth, and to Maira Araújo for their comments which helped improve this manuscript.

\section{References}

Alcantara DMC, Graciolli G, Nihei SS (2019) Revision of Noctiliostrebla (Diptera: Streblidae), parasites of bulldog bats (Chiroptera: Noctilionidae: Noctilio). Zootaxa 4560 (3): 483. https://doi.org/ 10.11646/zootaxa.4560.3.4

Almeida J, Gettinger D, Gardner SL (2016) Taxonomic review of the wingmite genus Cameronieta (Acari: Spinturnicidae) on Neotropical bats, with a new species from Northeastern Brazil. Comparative Parasitology 83 (2): 212-220. https://doi.org/10.1654/4788i.1

Autino AG, Claps GL, Barquez RM, Díaz MM (2011) Ectoparasitic insects (Diptera: Streblidae and Siphonaptera: Ischnopsyllidae) of bats from Iquitos and surrounding areas (Loreto, Peru). Memórias do Instituto Oswaldo Cruz 106 (8): 917-925.

Beck JD, Loftis AD, Daly JL, Reeves WK, Orlova MV (2016) First record of Chiroderma improvisum Baker \& Genoways, 1976 (Chiroptera: Phyllostomidae) from Saint Kitts, Lesser Antilles. Check List 12 (2): 1854. http://doi.org/10.15560/12.2.1854

Díaz MM, Solari S, Aguirre LF, Aguiar LMS, Barquez RM (2016) Clave de identificación de los murciélagos de Sudamérica. Programa de Conservación de los Murciélagos de Argentina (PCMA), Tucumán, Argentina, $160 \mathrm{pp}$.

Dick CW (2013) Review of the bat flies of Honduras, Central America (Diptera: Streblidae). Journal of Parasitology Research 2013: 437696. https://doi.org/10.1155/2013/437696

Dick CW, Gettinger D (2005) A faunal survey of streblid flies (Diptera: Streblidae) associated with bats in Paraguay. Journal of Parasitology 91 (5): 1015-1024. https://doi.org/10.1645/GE-536R.1

Dick CW, Guerrero R, Graciolli G (2016) Family Streblidae. Zootaxa 4122 (1): 784-802. https://doi.org/10.11646/zootaxa.4122.1.67

Dick CW, Miller JA (2010) Streblidae. In: Brown BV, Borkent A, Cumming JM, Wood DM, Woodley NE, Zumbado M (Eds.) Manual of Central American Diptera (Vol II). National Research Council Press, Ottawa, Canada, 1249-1260.

Dowling APG (2006) Mesostigmatid mites as parasites of small mammals: Systematics, ecology, and the evolution of parasitic associations. In: Morand S, Krasnov B, Poulin R (Eds.) Micromammals and macroparasites from evolutionary ecology to management. Springer Verlag, Tokyo, Japan, 103-118.

Dusbábek F (1968) Los ácaros cubanos de la familia Spinturnicidae (Acarina), con notas sobre su especificidad de hospederos. Poeyana, Serie A 57: 1-31.

Dusbábek F, Lukoschus F (1971) Some Spinturnicidae (Acarina: Mesostigmata) from Surinam bats. Parasitic mites of Suriname IX. Folia Parasitologica 18 (2): 149-154.

Estrada-Villegas S, Halczok TK, Tschapka M, Page RA, Brändel SD, Hiller T (2018) Bats and their bat flies: community composition and host specificity on a Pacific island archipelago. Acta Chiropterologica 20 (1): 161-176. https://doi.org/10.3161/15081109acc2018. 20.1.012

Garbino GST, Gregorin R, Lima IP, Loureiro L, Moras LM, Moratelli R, Nogueira MR, Pavan AC, Tavares VC, Peracchi AL (2020) Updated checklist of Brazilian bats: versão 2020. Comitê da Lista de Morcegos do Brasil_CLMB. Sociedade Brasileira para o Estudo de Quirópteros (Sbeq). https://www.sbeq.net/lista-de-especies. Accessed on: 2020-11-8.

Gettinger D (2018) Checklist of bloodfeeding mites (Acari: Spinturnicidae) from the wings of bats (Mammalia: Chiroptera) in the Manú Biosphere Reserve, Peru. MANTER: Journal of Parasite Diversity 10: 1-9. https://oi.org/10.13014/K2DJ5CVZ

Graciolli, G (2004) Nycteribiidae (Diptera, Hippoboscoidea) no Sul do Brasil. Revista Brasileira de Zoologia 21 (4): 971-985. https:// doi.org/10.1590/S0101-81752004000400035

Graciolli G (2010) Nycteribiidae. In: Brown BV, Borkent A, Cumming JM, Wood DM, Woodley NE, Zumbado M (Eds.) Manual of Central American Diptera (Vol. II). National Research Council Press, Ottawa, Canada, 1267-1273.

Graciolli G (2020) Streblidae in catálogo taxonômico da fauna do 
Brasil. COPPETEC-UFRJ. http://fauna.jbrj.gov.br/fauna/faunado brasil/262. Accessed on: 2020-11-8.

Graciolli G, Autino AG, Claps GL (2007) Catalogue of American Nycteribiidae (Diptera, Hippoboscoidea). Revista Brasileira de Entomologia 51 (2): 142-159.

Graciolli G, Azevedo AA (2011) Ectoparasites of bats (Chiroptera: Furipteridae), with a description of a new species of Synthesiostrebla Townsend (Diptera, Streblidae) from Brazil. Revista Brasileira de Entomologia 55 (4): 501-504.

Graciolli G, Dick CW (2009) A new species of Basilia Miranda-Ribeiro (Diptera: Nycteribiidae) from Honduras, parasite of Bauerus dubiaquercus (Van Gelder) (Chiroptera: Vespertilionidae: Antrozoinae). Zootaxa 1972 (1): 59-64. https://doi.org/10.11646/zoo taxa.1972.1.6

Graciolli G, Dick CW (2012) Description of a second species of Joblingia Dybas \& Wenzel, 1947 (Diptera: Streblidae). Systematic Parasitology 81 (3): 187-193. https://doi.org/10.1007/s11230$011-9338-3$

Graciolli G, Guerrero R, Catzeflis F (2019) Streblid bat flies (Diptera) and other ectoparasites on bats (Mammalia: Chiroptera) from French Guiana. Biota Neotropica 19 (4): e20180724. https://doi.org/ 10.1590/1676-0611-BN-2018-0724

Guerrero R (1994a) Catálogo de los Streblidae (Diptera: Pupipara) parásitos de murciélagos (Mammalia: Chiroptera) del Nuevo Mundo. II. Los grupos: pallidus, caecus, major, uniformis y longipes del genero Trichobius Gervais,1844. Acta Biológica Venezuélica 15: 1-18.

Guerrero R (1994b) Catálogo de los Streblidae (Diptera: Pupipara) parásitos de murciélagos (Mammalia: Chiroptera) del Nuevo Mundo. III. Trichobiinae con alas desarrolladas. Boletín de Entomología Venezolana, Nueva Serie 9: 161-192.

Guerrero R (1995) Catálogo de los Streblidae (Diptera: Pupipara) parásitos de murciélagos (Mammalia: Chiroptera) del Nuevo Mundo. V. Trichobiinae con alas reducidas o ausentes y miscelaneos. Boletín de Entomología Venezolana, Nueva Serie 10: 135-160.

Guerrero R (1996a) Catálogo de los Streblidae (Diptera: Pupipara) parásitos de murciélagos (Mammalia: Chiroptera) del Nuevo Mundo. VI. Streblinae. Acta Biológica Venezuélica 16 (2): 1-25.

Guerrero R (1996b) Streblidae (Diptera: Pupipara) parásitos de murciélagos de Pakitza, Parque Nacional Manu (Perú). In: Wilson DE, Sandoval A (Eds.) Manu: the biodiversity of southeastern Peru. Smithsonian Institution, Washington, DC, USA 627-641.

Guerrero R (2019) Streblidae (Diptera: Pupipara) de Venezuela: Sistemática, ecología y evolución. Editorial Académica Española, Mauritius, $600 \mathrm{pp}$.

Guimarães LR (1977) Supplemantary note on Venezuelan bat flies (Diptera: Nycteribiidae). Great Basin Naturalist 37 (2): 221-224.

Herrin CS, Tipton VJ (1975) Spinturnicid mites of Venezuela (Acarina: Spinturnicidae). Brigham Young University Sciences Bulletin, Biological Series 20 (2): 1-72.

Hrycyna G, Moreira-Martins AC, Graciolli G (2019) Infracommunities of bat flies (Diptera: Streblidae and Nycteribiidae) of bats (Mammalia: Chiroptera) in three conservation units in the state of Amapá, Brazil. Biota Neotropica 19 (4): e20180715. https://doi.org/ 10.1590/1676-0611-BN-2018-0715

Kunz TH, Kurta A (1988) Capture methods and holding devices. In: Kunz TH (Ed.) Ecological and behavioral methods for the study of bats. Smithsonian Institution Press, Washington, DC, USA, 1-28.

Marshall AG (1981) Ecology of ectoparasitic insects. Academic Press, London, UK, 459 pp.

Marinkelle CJ, Grose ES (1981) A list of ectoparasites of Colombian bats. Revista de Biología Tropical 29 (1): 11-20.

Miller C (2014) Host specificity and ectoparasite load of bat flies in Utila, Honduras. Senior Honors thesis, University of New Or- leans, New Orleans, USA, 21 pp.

Morales-Malacara JB, Castaño-Meneses G, Klompen H, Mancina CA (2020) New species of the Genus Periglischrus (Acari: Spinturnicidae) from Monophyllus bats (Chiroptera: Phyllostomidae) in the West Indies, including a morphometric analysis of its intraspecific variation. Journal of Medical Entomology 57 (2): 418 436. https://doi.org/10.1093/jme/tjz198

Pavan AC, Marroig G (2016) Integrating multiple evidences in taxonomy: species diversity and phylogeny of mustached bats (Mormoopidae: Pteronotus). Molecular Phylogenetics and Evolution 103: 184-198. https://doi.org/10.1016/j.ympev.2016.07.011

Ramírez-Chaves HE, Noguera-Urbano EA, Morales-Martínez DM, Zurc D, Vargas-Arboleda AF, Mantilla-Meluk H (2020) Endemic bats (Mammalia: Chiroptera) of Colombia: state of knowledge, distribution, and conservation. Universitas Scientiarum 25 (1): 55-94. https://doi.org/10.11144/Javeriana.SC25-1.ebmc

Ramírez-Martínez MM, Ibarra-Lopez MP, Iñiguez-Dávalos LI, Yuill T, Orlova MV, Reeves WK (2017) New records of ectoparasitic Acari (Arachnida) and Streblidae (Diptera) from bats in Jalisco, Mexico. Journal of Vector Ecology 41 (2): 309-313. https://doi. org/10.1111/jvec. 12228

Reeves WK, Loftis AD, Beck J (2013) A new species of Nycterophilia (Diptera: Streblidae) from the Antillean Fruit-eating Bat, Brachyphyila cavernarum (Chiroptera: Phyllostomidae). Journal of Entomological Science 48 (2): 114-117. https://doi.org/10.18474/0749-80 04-48.2.114

De la Sancha NU, López-González C, D’Elía G, Myers P, Valdez L, Ortiz ML (2017) An annotated checklist of the mammals of Paraguay. Therya 8 (3): 241-260. https://doi.org/10.12933/ therya-17-473

Sikes RS, Thompson TA, Bryan JA II (2019) American Society of Mammalogists: raising the standards for ethical and appropriate oversight of wildlife research. Journal of Mammalogy 100 (3): 763-773. https://doi.org/10.1093/jmammal/gyz019

Simmons NB, Cirranello AL (2020) Bats of the world. A taxonomic and geographic database. https://batnames.org/home.html. Accessed on: 2020-11-23.

ter Hofstede HM, Fenton MB, Whitaker JO Jr. (2004) Host and hostsite specificity of bat flies (Diptera: Streblidae and Nycteribiidae) on Neotropical bats (Chiroptera). Canadian Journal of Zoology 82 (4): 616-626. https://doi.org/10.1139/z04-030

Turcios-Casco MA, Ávila-Palma HD, LaVal RK, Stevens RD, Ordoñez-Trejo EJ, Soler-Orellana JA, Ordoñez-Mazier DI (2020) A systematic revision of the bats (Chiroptera) of Honduras: an updated checklist with corroboration of historical specimens and new records. Zoosystematics and Evolution 96 (2): 411-429. https://doi.org/10.3897/zse.96.51059

Urbieta GL, Torres JM, Carvalho-Dos Anjos EA, Espínola-Carvalho CME, Graciolli G (2018) Parasitism of bat flies (Nycteribiidae and Streblidae) on bats in urban environments: lower prevalence, infracommunities, and specificity. Acta Chiropterologica 20 (2): 511-518. https://doi.org/10.3161/15081109ACC2018.20.2.021

Wenzel RL (1976) The streblid batflies of Venezuela (Diptera: Streblidae). Brigham Young University Science Bulletin, Biological Series 20 (4): 1-177.

Wenzel RL, Tipton VJ, Kiewlicz A (1966) The streblid batflies of Panama (Diptera: Calyptera: Streblidae). In: Wenzel RL, Tipton VJ (Eds.) Ectoparasites of Panama. Field Museum of Natural History, Chicago, IL, USA, 405-675.

Whitaker JO Jr., JO, Ritzi CM, Dick CW (2009) Collecting and preserving ectoparasites for ecological study. In: Kunz JH, Parsons $\mathrm{S}$ (Eds.) Ecological and behavioral methods for the study of bats (2nd edition). John Hopkins University Press, Baltimore, MD, USA, 806-827. 